\title{
THE IMPACT OF INDIVIDUALIZING TASKS ON READING MOTIVATION AND PRACTICES OF UNIVERSITY-AGE VIETNAMESE NON-MAJORED EFL LEARNERS
}

\author{
NGUYEN TRUONG SA \\ Faculty of foreign languages, Industrial University of Ho Chi Minh City \\ nguyentruongsa@iuh.edu.vn
}

\begin{abstract}
The overarching purpose of this study was to measure how the sub-constructs of EFL reading motivation were influenced at both of their belief and action levels when the teacher gave more opportunity for the students to read and complete the tasks on their own purposes. Participants in this study were 70 students in 2 General English classes in a university in Ho Chi Minh City, Vietnam. The research was conducted using the pretest-posttest design in quasi-experiment research. To collect data, a questionnaire and focus group interview topics was created based on the Motivation for Reading Questionnaire (MRQ). Employing SPSS 25 software, the researcher ran Paired-sample T-test and One Way ANOVA to check the significant of the results from both of the control and experimental classes. It can be concluded that an increase in reading motivation and a more positive attitude toward reading have been confirmed. Noticeably, changes were observed to be developed at different degrees in all of the 8 constructs of the MRQ.
\end{abstract}

Key words: reading motivation, reading motivation constructs, reading practice.

\section{INTRODUCTION}

Reading (in EFL context) is a process of constructing meaning, a dialogue between the learners and the writer, a cognitively demanding skill which requires careful attention, memory, perceptual and comprehension processes, understanding words and sentences, along with a complex integration of the prior knowledge, experience, language proficiency, and metacognitive strategies [25], [51], [57], [12]. Besides, reading skills, achievement, and reading motivation seem inextricably linked [4], [11]. As a result, reading comprehension is often a laborious process for second and foreign language learners, especially at low-proficiency level. Many reading specialists [20], [31], [29], [57], [61], [63], [72] have suggested using authentic text and tasks for to improve reading comprehension ability and motivation to read in class. These scholars also emphasized the important of considering students' level of proficiency when choosing authentic text or designing task in teaching. Guariento and Morle [29] highlighted that at lower levels, even with quite simple tasks, "the use of authentic texts may not only prevent the learners from responding in meaningful ways but can also lead them to feel frustrated, confused, and, more importantly, demotivated" (p. 348). Therefore, although the teaching materials employed for EFL and ESL context around the world recently are highly authentic in the light of real-life texts, they do not seem to be student-friendly to low-level learners. Meanwhile, constructivist reading research listed five central factors that the reader matter in reading comprehension: reader skills, reader knowledge, reader cognitive development, reader culture, reader purpose [51]. Under teachers' instruction in any particular reading classroom, among the five 5 mentioned factors, reader purpose seem to be most receptive and ready for change. Gambrell et al. [25] also believed that highly motivated students would read for a wide variety of reasons, including curiosity, involvement, social interchange, and emotional satisfaction. This situation indicated a need for more research in related area which inspired the initiation of the present study. In EFL teaching context of the author in Vietnam, it has been observed that most university-age EFL students, despite having been learning with chosen real texts, are still facing particular challenges in motivation to read and to improve their reading ability. Therefore, in supposing that real text only may not detemine the degree of university-age students' reading motivation, the aim of this study was to empirically check whether fulfilling their individual reading purposes with adpated tasks helps to make any change on their motivation and practices. 


\section{LITERATURE FRAMEWORK}

\subsection{Definitions of EFL reading motivation}

Scholars in reading education have investigated the role of motivation in first language reading [74], [75] and found that beliefs, values, and the goals of reading can influence reading motivation. While L2 reading comprehension is the ability to read and process a text and understand its meaning [12] and reading motivation is an "individual's personal goals, values, and beliefs with regard to the topics, processes, and outcomes of reading" [30, 405] or the emotional drive that makes people read in an L2 [15]. Accordingly, reading motivation is highly individual attributed; an individual's reading motivation may also differ depending on environmental reading context [17], [47], [64], [65] and by the way the material is presented [49]. Motivation was used to be seen as a stable individual difference factor, but researchers have been focusing increasingly on the dynamic and changeable nature of the motivation process. In steal, student motivation can be successfully explored using a dynamic systems framework; motivation changes over time on an individual level while also being characterized by predictable and stable phases.

\subsection{Reading motivational constructs}

Most researchers agree that reading motivation includes sub-constructs which strongly affect reading practices and achievement [33], [66], [71], [74]. These constructs include instrumental orientation, attitudes toward L1 reading, interest in L2 language and culture, language learning beliefs, attitudes toward L2 study [5], or as Lin, Wong, and McBride-Chang's finding in 2012 [45], the constructs are self-efficacy, curiosity, involvement, recreation, grade, instrumentalism, social-family, and social-peer. Wang and Guthrie [70], however, proposed an eight-dimensional model. Wang and Guthrie's model retained only those related to the concepts of intrinsic and extrinsic motivation. Schiefele et al. [66] defined intrinsic motivation as the willingness to read because that activity is satisfying or rewarding in its own right while external motivation to read is tied to a factor outside the activity of reading itself or what the text has to offer the reader. Three of Wang and Guthrie's constructs - curiosity, involvement, and preference for challenge - were associated with intrinsic motivation. Five remaining constructs of Wang and Guthrie - competition, compliance, recognition for reading, grades, and social - were associated with extrinsic motivation. An extrinsicallymotivated reader, therefore, was expected to read to fulfill requirements, outperform peers, obtain good evaluations and recognition from others, and share what he/she reads with others.

\subsection{EFL reading motivation and reading behaviour}

Positive relationships between motivation and reading behavior, especially reading amount, were found in [18], [16], [35], [51], [13], [59], [60], [61], [67], [68]. These studies examined motivation from a psychological perspective and are based on an underlying assumption that motivation plays an important role in facilitating reading. These studies also illustrate that understanding of multi-dimensional nature of motivation assist to examine the relationships between motivation and reading behavior and design L2 reading instruction that nurtures student motivation. Although students' may also need to take active roles such as constantly monitoring the relation between the goals they have set and the text [19], [58], monitoring their own thinking [56], [62], figuring out unfamiliar words [27], negotiating meaning, using a strategy, knowing when to construct meaning [50], [55] when participating in reading, teachers' role in motivate and engage students' motivation is a key factor in comprehension [26], [50]. Importantly, teaching for a variety of purposes, using diverse methods, materials emerged as central parts of teacher's duties in scaffolding reading comprehension.

\subsection{The role of text and task authentcity in motivating students to read}

Many studies believed that students should have abundance exposures to use of English in real context because authentic materials are able to stimulate students' motivation to learn [1], [2], [8], [9], [23], [26], [50], [63, [69]. Compared to artificial materials which are made for learning purposes only, authentic text is believed to be more effective in providing students with opportunities to intermingle with real uses of language, stimulate their interest to read, give them the feeling that they are learning the 'real language'. Moreover, reading tasks should be authentic too to get the learners prepared for the reality of language use [8], [29], [63], [69], [78]. One of the crucial aspects of task authenticity is whether real communication takes place; whether the language has been used for a genuine purpose [29], [73]. Berardo [8] remarked that authenticity is the interaction that is established between the text and the reader. Berardo [8] views 
authenticity as a continuing process which is "beyond the context of the text". For this, it was recommended that the way the students read should match their own purpose of reading [8], [29], [63], [73]. Consequently, one of the most challenging tasks of second language and foreign language teachers are seeking to find the means, activities, and tasks to help language learners achieve their goals in learning languages. In other to create activities where the (target) language is used by the learners for a communicative purpose, a number of scholars recommend the employment of task-based method [12], [21], [54], [43], [46], [76]. However, some scholars also warn that task-based instructors (teachers) would face with many of individual needs and goals [14], [43], [46]. If language learners want to attain objectives of a reading task, the primary goal of a task should reflect what learners need to do in real-life situations [14]. Besides, as noted by Guariento and Morley [29], at lower levels, even with quite simple tasks, unless they have been very carefully selected for lexical and syntactic simplicity and/or content familiarity/predictability, the use of authentic texts can also lead them to feel frustrated, confused, and even demotivated.

\subsection{The research questions:}

When examined under issues debated in the literature, it could be noted that in different EFL classroom contexts in Vietnam, most currently adopted reading materials might be already highly authentic as being taken and designed from real-life text with careful consideration of learners' language level and ability. However, the degree that the materials were employed naturally and appropriately in cultural, situational, and personal contexts as suggested by the literature to motivate learners were still not reported. As a result, evidences of the impact of task autenticity on reading motivation were rare and unclear. Therefore, this study examined if the classroom provides the conditions in which the individual learners can read and complete tasks on their own purpose, then how it played its authenticating role productively on different motivational constructs. Besides, the literature has also pointed out that learners have their own ways of dealing with different classroom contexts [3], [10], [77] and manage their learning by constantly taking advantage of these contexts for their own learning purposes [41] by constantly struggling to create their own meanings [7], [41]. As learners are not passive recipients' but to various degrees capable of reflecting on learning experience [7], [32], [36] this study also examined how the experiment affected their reading behaviors. The two questions that guided this research study are:

1. What are the impacts of individualized reading purposes on students' motivation constructs?

2. What are the impacts of this technique on their reading practices inside and outside classroom?

\subsection{The significant of the study}

The study is highly important in the light of contribution to both practical value and theoretical framework. Practically, the studied topic reflexes reality of motivating learners in reading comprehension classrooms where authentic text may be employed intensively with much lower level of consideration on task and learner authenticity. Theoretically, while a number of studies have developed a fundamental argument on the positive relationship between reading motivation as a general construct and student's reading tasks, the overarching purpose of this study is to measure how the sub-constructs of EFL reading motivation, and reading practice as well, were influenced when the teacher gave more opportunity for the students to read and complete the tasks on their own purposes.

\section{RESEARCH DESIGN}

\subsection{The participants:}

Participants in this study were 70 students in 2 General English classes from Industrial University of Ho Chi Minh City. They, aging from 18 to 21 years old, come from different majors in the university and registered for English class as a compulsory course. The 45-classroom-period course was TOEIC oriented; the expected outcome of the classes was TOEIC at 450-level. According to the schedule, the students had to attend a classroom section of 3 periods in length (50 minutes per period) and spend at least 6 hours for self-study per week. According to the course requirement, in the reading comprehension class, all the texts had topics or situations that they would likely encounter on a regular basis in a daily and business environment such as e-mails, brochures, regulations, policy changes, announcements, presentations, letters, resumes, proposals and reports, online chats, instant messaging, or text messaging involving multiple writers. All the questions are multiple-choice with only one correct answer to choose. Therefore, although the material was already highly authentic, most common teaching method among the teachers was 
employing the pre-designed tasks in the course book and teaching for test. The teacher-in-charge of the 2 classes was 36 years old; he achieved a master degree in TESOL in Australia and had over 8 years of teaching TOEIC preparation for university-age students in Vietnam.

\subsection{The experiment tasks}

Under the approved consent to add authentic tasks to teach the 2 classes, the reading comprehension activities designed for the students aimed to ensure that learners were given plentiful opportunities to read and complete the tasks according to their interest, perception, and goals under the teacher's facilitation. Being adopted the available texts in the course book, the tasks were re-designed based on the activities and 3-stage principle of task-based teaching, namely pre-task, task-cycle, and post-task [22], [37], [38], [39], [52], [53], [76]. In pre-task, the teacher introduces the task, the students will recall and activate their knowledge of the topics and do lots of brainstorming activities. In task cycle, task-students carry out the task through planning, doing, and reporting their completion of the task. In language focus stage, students analyze and assess the completions of tasks and practice the language difficulties under the direction of the teacher. There were different types of tasks provided to the students in each lesson and they were allowed to choose a task they preferred. Then, based on each particular task, they were arranged to complete the task individually or in group. In a typical lesson, the outcome of the tasks was evaluated in groups or whole class in the last 50 minutes; the processes varied enormously depending on the type and complexity of the problem but the most frequent activities were organised as individual and/or group presentation, poster exhibition, and games. In each lesson, the tasks for the students to choose could be:

- With e-mails, letters: listing the main purposes/ideas of the writer, listing the further information that you need, guessing the content of the previous email/letter, and writing a simple/short response if you were the receiver.

- With regulations, policy changes, new policies: listing the possible positive and negative consequences of the changes, revising the changes to make them more relevant, listing what regulation/rules should be changed in your university.

- With announcements, presentations: deciding what you should pay attention from the provided content, sharing your own experience/lesson from the text, what would be wrong/problematic with the provided content in another context.

- With online chats, instant messaging, or text messaging: Writing a response, writing the possible previous message, writing another message with the same/most important content.

- With brochures, advertisement: drafting a mind map, listing, categorizing; and classifying items in different ways, proposing another similar product.

- With proposals and reports: making your own proposal/report, what could be propose/report further, summarizing the proposal/report.

- With resumes: drawing a mind map, evaluating the resumes, preparing questions for interview.

- Article/news: summarizing, guessing the headline, making rumors and gossips, making presentation.

\subsection{The data collecting and analysing methods}

Because reading motivation is a critical contributor to reading achievement and has the potential to influence its development, the most commonly used assessment of reading motivation is student self-report and researchers have developed multiple scales to measure reading motivation. According to a review of Marcia et al. [48], after 1990, a total of 16 student self-report scales of reading motivation and self-efficacy were found with different level of reliability and validity. To measure L2 reading motivation for this study, a questionnaire was created based on the Motivation for Reading Questionnaire (MRQ) used in Wang and Guthrie [70] and previously adapted by Komiyama [40]. The MRQ is considered to be the most comprehensive motivation measure currently available for L1 readers [44], [45]; the scale taps eight constructs of reading motivation namely: curiosity, involvement, challenge, competition, recognition, compliance, grade/score/passing English course, and social sharing. The 47-item questionnaire, which was carefully re-contextualized and translated into Vietnamese, requires the participants to write the response $(1,2,3$ or 4$)$ that tells how true each statement is.

1. Very different from me (means that the statement is not true of you almost always)

2. A little different from me (means is not true less than half the time) 
3. A little like me (the statement is true less than half the time of you almost always)

4. A lot like me (the statement is true of you about half the time)

The research was conducted using the pretest-posttest design in quasi-experiment research. Through convenience sampling, two intact classes were chosen and assigned as the experimental and the control group. The dependent variable was the 8 reading motivation constructs and reading practices of the participants and the independent variable was the method of teaching reading with two varieties of "individualized task-based activities" versus "pre-designed reading activities". Both the experimental and control groups' lesson plans were based on the same reading materials and schedule of instruction; the time between pre-test and post-test was long enough (14 weeks) to reduce the test-retest effect. Employing SPSS 25 software, the researcher ran paired-sample t-test and One Way ANOVA to check the significant of the results from both of the control and experimental classes. The analysis of paired-samples t-test was used to specify whether there was any changes in the eight motivational constructs according to experiencing the teaching method; the analysis of one-way ANOVA was administered to examine whether there were differences controlled and experiment group. Besides, the students in the experiment class were arranged into small groups from random 4 to 6 students; then 5 focus group interviews [6], [42] was carried out at the beginning and another 5 interviews at the end of the course to check the extent to which the experiment impacted on the reading practice. Topics for discussion in the groups were the 47 statements in the questionnaire, but in this phase of data collection the students were encouraged to share their story and reasons relating to or underlying their choices with their group-mates and teacher. While the researcher acted as a moderator during the group interaction, the students were encouraged to talk to one another, ask questions, exchange anecdotes and comment on one another's experiences and points of view. This form of group interview, as opposed to individual interviews, could encourage students to open up and talk freely about what they do in and outside their language classrooms in interactive groups. All of the interviews were carried out in their mother tongue; audiotapes of the discussions were transcribed as fully as possible, then the data was arranged in such a way that the transcript reads like a narrative in order to gain a better sense of what was being said from the students' viewpoint. Adopting the content analysis method [28], the data were analysed and coded inductively through a process starting from line-by-line analysis (open coding) to relating the open-codes to build themes/categories of reading practices based on valid inference, interpretation, and inductive reasoning.

\section{RESULT AND DISCUSSION}

\subsection{What are the impacts of individualized reading purposes on students' motivation constructs?}

In response to the first research question that assessed impacts of individualized reading purposes on students' eight motivation constructs, the study found statistically significant differences of the changes among the constructs after the course. T-test findings indicated that while the mean score of competition, recognition, compliance, grade/score/passing English course seemed to remain stable or increased very slightly. Meanwhile, the mean scores of rest four constructs tend to raise up more impressively and came closer to the scale 4 statement. Tables $1 \mathrm{a}, 1 \mathrm{~b}, 1 \mathrm{c}, 1 \mathrm{~d}$ include descriptive statistics, at the significance level lower than 0.05 ( $\mathrm{p}<0.05)$, of the pre-test (a) and post-test (b) on the experiment group $(\mathrm{N}=35)$ on how the mean scores of competition, recognition, compliance, grade/score/pass showed little changes.

Table 1a: Paired Samples Statistics of the construct competition

\begin{tabular}{|c|c|c|c|c|c|}
\hline & & Mean & $\mathrm{N}$ & Std. Deviation & $\begin{array}{l}\text { Std. Error } \\
\text { Mean }\end{array}$ \\
\hline \multirow[t]{2}{*}{ Pair 1} & Competition $17 \mathrm{a}$ & 1.60 & 35 & .736 & .124 \\
\hline & Competition $17 \mathrm{~b}$ & 1.80 & 35 & .759 & .128 \\
\hline \multirow[t]{2}{*}{ Pair 2} & Competition 18a & 2.03 & 35 & .785 & .133 \\
\hline & Competition $18 \mathrm{~b}$ & 2.17 & 35 & .747 & .126 \\
\hline \multirow[t]{2}{*}{ Pair 3} & Competition 20a & 2.23 & 35 & .877 & .148 \\
\hline & Competition $20 \mathrm{~b}$ & 2.40 & 35 & .812 & .137 \\
\hline \multirow[t]{2}{*}{ Pair 4} & Competition 21a & 1.86 & 35 & .733 & .124 \\
\hline & Competition $21 \mathrm{~b}$ & 2.06 & 35 & .802 & .136 \\
\hline \multirow[t]{2}{*}{ Pair 5} & Competition $23 \mathrm{a}$ & 1.86 & 35 & .879 & .149 \\
\hline & Competition $23 \mathrm{~b}$ & 2.06 & 35 & .906 & .153 \\
\hline
\end{tabular}


THE IMPACT OF INDIVIDUALIZING TASKS ON READING MOTIVATION AND PRACTICES OF UNIVERSITY-AGE VIETNAMESE NON-MAJORED EFL LEARNERS

\begin{tabular}{|l|l|l|l|l|l|}
\hline Pair 6 & Competition 24a & 1.91 & 35 & .781 & .132 \\
\cline { 2 - 6 } & Competition 24b & 2.20 & 35 & .677 & .114 \\
\hline \multirow{2}{*}{ Pair 7 } & Competition 27a & 1.71 & 35 & .622 & .105 \\
\cline { 2 - 6 } & Competition 27b & 1.83 & 35 & .664 & .112 \\
\hline Pair 8 & Competition 39a & 2.97 & 35 & .923 & .156 \\
\cline { 2 - 6 } & Competition 39b & 2.97 & 35 & .923 & .156 \\
\hline
\end{tabular}

Table 1b: Paired Samples Statistics of the construct recognition

\begin{tabular}{|l|l|c|c|c|c|}
\hline \multicolumn{2}{|c|}{} & Mean & $\mathrm{N}$ & Std. Deviation & Std. Error Mean \\
\hline \multirow{3}{*}{ Pair 1 } & Recognition 19a & 2.69 & 35 & .832 & .141 \\
\cline { 2 - 6 } & Recognition 19b & 2.71 & 35 & .825 & .139 \\
\hline Pair 2 & Recognition 22a & 2.23 & 35 & .731 & .124 \\
\cline { 2 - 6 } & Recognition 22b & 2.40 & 35 & .736 & .124 \\
\hline \multirow{2}{*}{ Pair 3 } & Recognition 25a & 2.20 & 35 & .719 & .122 \\
\cline { 2 - 6 } & Recognition 25b & 2.34 & 35 & .765 & .129 \\
\hline \multirow{3}{*}{ Pair 5 } & Recognition 26a & 2.91 & 35 & .818 & .138 \\
\cline { 2 - 6 } & Recognition 26b & 2.86 & 35 & .879 & .149 \\
\hline \multirow{2}{*}{ Pair 6 } & Recognition 28a & 3.37 & 35 & .547 & .092 \\
\cline { 2 - 6 } & Recognition 28b & 3.37 & 35 & .547 & .092 \\
\cline { 2 - 6 } Pair 7 & Recognition 29a & 1.77 & 35 & .877 & .148 \\
\cline { 2 - 6 } & Recognition 29b & 1.83 & 35 & .891 & .151 \\
\hline
\end{tabular}

Table 1c: Paired Samples Statistics of the construct compliance

\begin{tabular}{|l|l|c|c|c|c|}
\hline \multicolumn{2}{|c|}{} & Mean & $\mathrm{N}$ & Std. Deviation & Std. Error Mean \\
\hline \multirow{2}{*}{ Pair 1 } & Compliance 30a & 3.43 & 35 & .558 & .094 \\
\cline { 2 - 6 } & Compliance 30b & 3.43 & 35 & .558 & .094 \\
\hline \multirow{2}{*}{ Pair 2 } & Compliance 31a & 3.49 & 35 & .562 & .095 \\
\cline { 2 - 6 } & Compliance 31b & 3.43 & 35 & .558 & .094 \\
\hline \multirow{2}{*}{ Pair 3 } & Compliance 33a & 3.57 & 35 & .558 & .094 \\
\cline { 2 - 6 } & Compliance 33b & 3.54 & 35 & .561 & .095 \\
\hline \multirow{2}{*}{ Pair 4 } & Compliance 40a & 3.37 & 35 & .547 & .092 \\
\cline { 2 - 6 } & Compliance 40b & 3.37 & 35 & .547 & .092 \\
\hline
\end{tabular}

Table 1d: Paired Samples Statistics of the construct grade and score

\begin{tabular}{|l|l|c|c|c|c|}
\hline \multicolumn{2}{|c|}{} & Mean & $\mathrm{N}$ & Std. Deviation & Std. Error Mean \\
\hline Pair 1 & Grade and Score 32a & 3.46 & 35 & .561 & .095 \\
\cline { 2 - 6 } & Grade and Score 32b & 3.49 & 35 & .562 & .095 \\
\hline \multirow{2}{*}{ Pair 2 } & Grade and Score 34a & 3.51 & 35 & .507 & .086 \\
\cline { 2 - 6 } & Grade and Score 34b & 3.57 & 35 & .502 & .085 \\
\hline \multirow{2}{*}{ Pair 3 } & Grade and Score 35a & 3.66 & 35 & .482 & .081 \\
\cline { 2 - 6 } & Grade and Score 35b & 3.66 & 35 & .482 & .081 \\
\hline \multirow{2}{*}{ Pair 4 } & Grade and Score 36a & 3.57 & 35 & .502 & .085 \\
\cline { 2 - 6 } & Grade and Score36b & 3.57 & 35 & .502 & .085 \\
\hline \multirow{2}{*}{ Pair 6 } & Grade and Score 37a & 3.49 & 35 & .742 & .126 \\
\cline { 2 - 6 } & Grade and Score 37b & 3.54 & 35 & .741 & .125 \\
\hline & Grade and Score 38a & 3.49 & 35 & .702 & .119 \\
\hline Pair 7 & Grade and Score 38b & 3.43 & 35 & .698 & .083 \\
\cline { 2 - 6 } & Grade and Score 47a & 3.63 & 35 & .490 & .075 \\
\hline
\end{tabular}

As it is observed in the tables above, among the reported paired constructs, there were no change in the mean scores of 6 pairs of competition 39a-b, recognition 28a-b, compliance 30a-b, 40a-b, and grade and score 35a-b, 36a-b. For the other pairs, evidences of the differences between the pre-test and posttest mean scores were not strong enough to conclude a clear influence of the method on the participants. Analysis of 
the mean scores across the pairs in tables $1 \mathrm{a}, 1 \mathrm{~b}, 1 \mathrm{c}, 1 \mathrm{~d}$ show that, there were very tiny changes in the compliance construct and the grade and score construct. The most significant statistics in these groups of constructs can be interpreted based on the result of the pair competition 24a-b; when rated for the statement "when some classmates read English better than me, I want to read more English materials", the mean scores of the pre-test and post-test were respectively 1.91 and 2.20 .

On the contrary, in the constructs of curiosity, involvement, challenge, and social, it is interesting to note that students made considerable choices of higher scales compared to the pre-test. That made the mean scores in the post-test of the four constructs much higher than those in the pre-test. The statistical results in table $2 \mathrm{a}, 2 \mathrm{~b}, 2 \mathrm{c}$, and $2 \mathrm{~d}$ show that there were sharp increases in the mean scores after the experiment. According to the result, the most impressive increase was observed in the construct social where the mean scores of 4 out of 5 pairs in the group rose dramatically from around 1 to upper than 3 . Besides, noticeable increase in the mean score was also presented in results of the pairs such as curiosity 1a-b, involvement 2a$\mathrm{b}$, involvement $11 \mathrm{a}-\mathrm{b}$, involvement $14 \mathrm{a}-\mathrm{b}$, and challenge $8 \mathrm{a}-\mathrm{b}$. Although the other pairs in these 4 constructs showed smaller changes compared to other pairs in their groups, the changes were observed to be much impressive than those of the constructs listed in table $1 \mathrm{a}, 1 \mathrm{~b}, 1 \mathrm{c}$, and $1 \mathrm{~d}$.

Table 2a: Paired Samples Statistics of the construct grade and score

\begin{tabular}{|l|l|c|c|c|c|}
\hline \multicolumn{2}{|c|}{} & Mean & $\mathrm{N}$ & Std. Deviation & Std. Error Mean \\
\hline Pair 1 & Curiousity 1a & 2.94 & 35 & .802 & .136 \\
\cline { 2 - 6 } & Curiousity 1b & 3.66 & 35 & .539 & .091 \\
\hline Pair 2 & Curiousity 3a & 3.09 & 35 & .781 & .132 \\
\cline { 2 - 6 } & Curiousity 3b & 3.63 & 35 & .690 & .117 \\
\hline Pair 3 & Curiousity 7a & 3.34 & 35 & .684 & .116 \\
\cline { 2 - 6 } & Curiousity 7b & 3.69 & 35 & .583 & .098 \\
\hline Pair 4 & Curiousity 15a & 2.63 & 35 & .598 & .101 \\
\cline { 2 - 6 } & Curiousity 15b & 3.40 & 35 & .651 & .110 \\
\hline Pair 5 & Curiousity 16a & 3.00 & 35 & .840 & .142 \\
\cline { 2 - 6 } & Curiousity 16b & 3.57 & 35 & .558 & .094 \\
\hline
\end{tabular}

Table 2b: Paired Samples Statistics of the construct grade and score

\begin{tabular}{|l|l|c|c|c|c|}
\hline \multicolumn{2}{|c|}{} & Mean & $\mathrm{N}$ & Std. Deviation & Std. Error Mean \\
\hline \multirow{2}{*}{ Pair 1 } & Involvement 2a & 2.40 & 35 & .775 & .131 \\
\cline { 2 - 6 } & Involvement 2b & 3.37 & 35 & .731 & .124 \\
\hline Pair 2 & Involvement 5a & 3.09 & 35 & .702 & .119 \\
\cline { 2 - 6 } & Involvement 5b & 3.71 & 35 & .519 & .088 \\
\hline Pair 3 & Involvement 6a & 2.71 & 35 & .622 & .105 \\
\cline { 2 - 6 } & Involvement 6b & 3.26 & 35 & .780 & .132 \\
\hline \multirow{2}{*}{ Pair 4 } & Involvement 11a & 1.34 & 35 & .906 & .153 \\
\cline { 2 - 6 } & Involvement 11b & 3.31 & 35 & .796 & .135 \\
\hline Pair 5 & Involvement 14a & 1.80 & 35 & .868 & .147 \\
\cline { 2 - 6 } & Involvement 14b & 3.34 & 35 & .639 & .108 \\
\hline
\end{tabular}

Table 2c: Paired Samples Statistics of the construct grade and score

\begin{tabular}{|l|l|c|c|c|c|}
\hline \multicolumn{2}{|c|}{} & Mean & $\mathrm{N}$ & Std. Deviation & Std. Error Mean \\
\hline \multirow{2}{*}{ Pair 1 } & Challenge 4a & 2.26 & 35 & .817 & .138 \\
\cline { 2 - 6 } & Challenge 4b & 3.43 & 35 & .739 & .125 \\
\hline Pair 2 & Challenge 8a & 1.80 & 35 & .759 & .128 \\
\cline { 2 - 6 } & Challenge 8b & 3.40 & 35 & .736 & .124 \\
\hline Pair 3 & Challenge 9a & 2.54 & 35 & .611 & .103 \\
\cline { 2 - 6 } & Challenge 9b & 3.17 & 35 & .747 & .126 \\
\hline Pair 4 & Challenge 10a & 2.34 & 35 & .968 & .164 \\
\cline { 2 - 6 } & Challenge 10b & 3.37 & 35 & .646 & .109 \\
\hline Pair 5 & Challenge 12a & 1.77 & 35 & .808 & .136 \\
\cline { 2 - 6 } & Challenge 12b & 2.97 & 35 & .785 & .119 \\
\hline \multirow{2}{*}{ Pair 6 } & Challenge 13a & 2.51 & 35 & .702 & .101 \\
\cline { 2 - 6 } & Challenge 13b & 3.37 & 35 & .598 & \\
\hline
\end{tabular}


Table 2d: Paired Samples Statistics of the construct grade and score

\begin{tabular}{|l|l|c|c|c|c|}
\hline \multicolumn{2}{|c|}{} & Mean & $\mathrm{N}$ & Std. Deviation & Std. Error Mean \\
\hline Pair 1 & Social 41a & 2.54 & 35 & .852 & .144 \\
\cline { 2 - 6 } & Social 41b & 3.23 & 35 & .598 & .101 \\
\hline Pair 2 & Social 42a & 1.97 & 35 & .707 & .119 \\
\cline { 2 - 6 } & Social 42b & 3.37 & 35 & .843 & .143 \\
\hline Pair 3 & Social 43a & 1.83 & 35 & .891 & .151 \\
\cline { 2 - 6 } & Social 43b & 3.63 & 35 & .646 & .109 \\
\hline Pair 4 & Social 44a & 1.89 & 35 & .796 & .135 \\
\cline { 2 - 6 } & Social 44b & 3.29 & 35 & .789 & .133 \\
\hline Pair 5 & Social 46a & 1.77 & 35 & .808 & .136 \\
\cline { 2 - 6 } & Social 46b & 3.17 & 35 & .857 & .145 \\
\hline
\end{tabular}

Table 3 includes examples of the descriptive statistics to illustrate the result of the ANOVA test. Owing to ANOVA test results, with the sig. of the post-test (b) were lower than $(0.05)$ or zero (except for the question curiosity 16), significant differences were also observed between the controlled and the experiment groups in the four constructs of curiosity, involvement, challenge, and social sharing. Meanwhile, the significant level of the test showed that, with the sig. of the post-test (b) is higher than (0.05) (except for the questions competition 17 and 24), the influence of the experiment on the four constructs of competition, recognition, compliance, and grade passing cannot be concluded. The ANOVA confirmed the result from paired sample T-test, that is to say, statistical evidences showed that the experiment influence much stronger on some reading motivational constructs than other constructs in the MRQ scale.

Table 3: examples from the One way ANOVA result

\begin{tabular}{|c|c|c|c|c|c|c|}
\hline & & Sum of Squares & $\mathrm{df}$ & Mean Square & $\mathrm{F}$ & Sig. \\
\hline \multirow[t]{3}{*}{ Curiousity $7 \mathrm{~b}$} & Between Groups & 3.214 & 1 & 3.214 & 6.033 & .017 \\
\hline & Within Groups & 36.229 & 68 & .533 & & \\
\hline & Total & 39.443 & 69 & & & \\
\hline \multirow[t]{3}{*}{ Involvement 5b } & Between Groups & 2.414 & 1 & 2.414 & 9.641 & .003 \\
\hline & Within Groups & 17.029 & 68 & 250 & & \\
\hline & Total & 19.443 & 69 & & & \\
\hline \multirow[t]{3}{*}{ Challenge $9 b$} & Between Groups & 4.629 & 1 & 4.629 & 10.907 & .002 \\
\hline & Within Groups & 28.857 & 68 & .424 & & \\
\hline & Total & 33.486 & 69 & & & \\
\hline \multirow[t]{3}{*}{ Competition $18 \mathrm{~b}$} & Between Groups & .514 & 1 & 514 & .714 & .401 \\
\hline & Within Groups & 48.971 & 68 & .720 & & \\
\hline & Total & 49.486 & 69 & & & \\
\hline \multirow[t]{3}{*}{ Recognition 19b } & Between Groups & .129 & 1 & .129 & .187 & .667 \\
\hline & Within Groups & 46.743 & 68 & .687 & & \\
\hline & Total & 46.871 & 69 & & & \\
\hline \multirow[t]{3}{*}{ Compliance 31b } & Between Groups & .914 & 1 & 914 & 3.368 & .071 \\
\hline & Within Groups & 18.457 & 68 & .271 & & \\
\hline & Total & 19.371 & 69 & & & \\
\hline \multirow{3}{*}{$\begin{array}{l}\text { Grade and } \\
\text { Score } 32 b\end{array}$} & Between Groups & .057 & 1 & .057 & .200 & .656 \\
\hline & Within Groups & 19.429 & 68 & .286 & & \\
\hline & Total & 19.486 & 69 & & & \\
\hline \multirow[t]{3}{*}{ Social 41b } & Between Groups & 30.229 & 1 & 30.229 & 47.899 & .000 \\
\hline & Within Groups & 42.914 & 68 & .631 & & \\
\hline & Total & 73.143 & 69 & & & \\
\hline
\end{tabular}

4.2. What are the impacts of this technique on their reading practices inside and outside classroom?

Results and evidences from focus group interviews also suggested that there were considerable impacts of the experiment on the practices of the participants. Generally, similar to the quantitative result from the pretest and post-test questionnaire, the participants showed changed in their beliefs, attitudes, and actions towards reading in ESL in and outside class. The changes were also observed to be developed at different 
degrees in all of the 8 constructs. Tables $4 \mathrm{a}$ and $4 \mathrm{~b}$ summarize and compare themes inferred from the participants' voice in the controlled group toward reading comprehension in foreign language at the beginning and the end of the course. Interestingly, evidences of changes in the 4 constructs of curiosity, involvement, challenge, and social were recognized to be most observable and explainable. In the interview data, it seemed that there was no change in the 3 constructs of competition, recognition, and compliance. Consistently throughout the course, the students showed that they concentrated more on improving their grade to pass the course than caring much about competing with any other particular learner or trying being evaluated as a good learner in class. At the end of the course, the students were more motivated to learn more structures and vocabulary for test; they even searched and practiced mock tests more often at home. Most of them tried to complete at least one reading mock test every 2 weeks and admitted that they often administrated their own progress by comparing score after completing the test. After that, they worked again over the reading passages in the test for useful vocabularies, knowledge, and experiences. They strongly argued that understanding what they want to read is more important than reading better than someone else and the most important in learning is managing their own improvement. Despites admitting that positive comment from teacher made them more confident and motivated, every of their single effort in learning was explained as not for being praised or recognized. Besides, attempts to learn language form and rules, learning strategies, exams skills in class and at home also showed that following guidance strictly was a strong belief to inform their actions.

Table 4a: Participants' voice toward reading comprehension in foreign language

\begin{tabular}{|c|c|c|}
\hline & \multicolumn{2}{|c|}{ Scale } \\
\hline & Pre-course & Post-course \\
\hline Competition & $\begin{array}{l}\text { - Understanding what I want to read is more } \\
\text { important than reading better than someone } \\
\text { else. } \\
\text { - Working out an accurate answer is more } \\
\text { important than giving an early but incorrect } \\
\text { answer. } \\
\text { - Recognizing my self-improvement is more } \\
\text { important than catching up with others. } \\
\text { - Using achievement of other people as goal } \\
\text { is not a good learning strategy }\end{array}$ & $\begin{array}{l}\text { - Understanding what I want to read is more } \\
\text { important than reading better than someone } \\
\text { else. } \\
\text { - Caring too much about others achievement is } \\
\text { not good for my learning. } \\
\text { - Competing with myself is the most important } \\
\text { - Being one of the best students in the class is } \\
\text { not my goal. }\end{array}$ \\
\hline Recognition & $\begin{array}{l}\text { - Being praised by teachers in front of others } \\
\text { in class is less important than working out the } \\
\text { correct answer myself. } \\
\text { - Being praised for a correct answer is less } \\
\text { important than being corrected } \\
\text { - Recognizing my own mistakes and } \\
\text { improvement is more important than being } \\
\text { recognized as a good reader in class. }\end{array}$ & $\begin{array}{l}\text { - Recognizing my own mistakes and } \\
\text { improvement is more important than being } \\
\text { praised for a correct answer. } \\
\text { - Helping someone for peer-improvement, not } \\
\text { for proving that I'm a better partner in group. } \\
\text { - Positive comment from teacher made me feel } \\
\text { more confident with my answers and motivated } \\
\text { to read }\end{array}$ \\
\hline Compliance & $\begin{array}{l}\text { - Time management is very important } \\
\text { - Following teacher's guidance is crucial in } \\
\text { practicing } \\
\text { - Rules, forms, strategies, and methods } \\
\text { should be strictly followed }\end{array}$ & $\begin{array}{l}\text { - Time management is very important } \\
\text { - Following teacher's guidance, reading } \\
\text { strategies is crucial in practicing } \\
\text { - Rules, forms, strategies, and methods should } \\
\text { be strictly followed }\end{array}$ \\
\hline Grade /Score & $\begin{array}{l}\text { - Improving score/grade is my ultimate goal } \\
\text { - Score/grade is one of the most exact } \\
\text { indicator of my level } \\
\text { - Spending more time to practice at home is } \\
\text { my strategy } \\
\text { - Learning new vocabularies helps to } \\
\text { improve my reading }\end{array}$ & $\begin{array}{l}\text { - Improving score/grade is my ultimate goal } \\
\text { - International score/grade is the most exact } \\
\text { indicator of my level } \\
\text { - Spending more time to practice at home is } \\
\text { my strategy } \\
\text { - My habbit of learning new vocabularies } \\
\text { practice mock test will help improve score }\end{array}$ \\
\hline
\end{tabular}

Meanwhile, a number of obvious changes were confirmed from the interview sections related to curiosity, involvement, challenge, and social sharing topics. As can be observed in table $2 \mathrm{~b}$, compared to the past 
interviews, content of the interview at the end of the course prevail emerged that the participants had made clear adjustments on their way of practice reading. For instant, the participants used to believe strongly that their central goal should be working on the reading passages in the textbooks and mock-test booklets, the content of the passages were simply for completing the task and learning new vocabulary. Therefore, what attracted them previously were solely the test strategies, test-type questions, reading strategies, and almost any unfamiliar vocabulary. Besides, when reading, they often involved themselves in silent translation as a way to grasp the meaning of text. However, they admitted that they formulated a habit of paying more attention to cultural and professional knowledge and experience enclosed in the reading texts. To save more time and concentration for more intensive reading, range of need-to-learn vocabulary were also narrowed down; the chosen lexical items to be memorized were therefore short-listed to be more relevant to daily and professional needs. The students also noted that they involved themselves more into classroom activities and were readier to try participating on challenging tasks. At the beginning, most of them claimed that reading in mother tongue was one of their pastime habits, but they gradually used more time to read short posts written in English, English learning tips and strategies, news headings, and proverbs that shared on the facebook. In spite of still trying to avoid texts that have a long and complicated look, they were more willing to work on materials believed to be authentic for more proficiency levels. While they were students at TOEIC 350 level, when asked about kinds of materials they chose to take self-practice, most of them admitted that they adopted real mock test or reading passages for TOEIC 400 or 450 level. Besides, a feeling of much more confident was also confirmed among the students when discussing the reaction and attitude towards facing with the why and how questions and questions that require inference and implication skill. At the beginning, almost every students in the class claimed that interactive reading activities such as group work, presentation, discussion, experience sharing, etc. made them felt anxious and that they would prefer it when working individually. At the end of the course, however, most of them acknowledged that they had been much more confident to participate in group-activities or to express their ideas in class. They had even spent more time at home to prepare better for activities in the coming lesson. Interestingly, they were more willing to read and share simple interesting texts, short-posts, English learning tips and strategies, news headings, and proverbs written in English that shared on the facebook. Some of them also reported that they had been trying to text short messages in English to their friends.

Table 4b: Participants' voice toward reading comprehension in foreign language

\begin{tabular}{|c|c|c|}
\hline Curiosity & $\begin{array}{l}\text { - Completing the tasks in the books and } \\
\text { mock-test is my central attention } \\
\text { - I always try to sharpen my reading } \\
\text { strategies to get higher score } \\
\text { - The content of the text are helpful for } \\
\text { answering the questions and learning } \\
\text { vocabulary }\end{array}$ & $\begin{array}{l}\text { - Completing the tasks in the books and mock-test, } \\
\text { and strategies is my central attention. } \\
\text { - There are a number of interesting information } \\
\text { about culture, life, experiences in the reading text. } \\
\text { - The content of the text are helpful for learning } \\
\text { necessary vocabulary. }\end{array}$ \\
\hline Involvement & $\begin{array}{l}\text { - Completing the tasks in the books and } \\
\text { mock-test is my central attention } \\
\text { - I always note new strategies to get higher } \\
\text { score } \\
\text { - Long and complicated texts are not for } \\
\text { my level } \\
\text { - Reading in my mother tongue is much } \\
\text { easier and more exciting } \\
\text { - Translation was an important skill to help } \\
\text { them grasp the meanings of English texts }\end{array}$ & $\begin{array}{l}\text { - There may be number of interesting information } \\
\text { about culture, life, experiences in the reading text. } \\
\text { - We are more willing to read things that attract us. } \\
\text { For example, short-posts written in English that } \\
\text { shared on the facebook, English learning tips and } \\
\text { strategies, news headings, proverbs... } \\
\text { - Long and complicated texts like news articles, } \\
\text { stories are not for me at this stage }\end{array}$ \\
\hline
\end{tabular}




\begin{tabular}{|c|c|c|}
\hline Challenge & $\begin{array}{l}\text { - When the topic is relevant to my major of } \\
\text { study, I am MORE willing to read difficult } \\
\text { English materials. } \\
\text { - Long and complicated texts are not for } \\
\text { my level } \\
\text { - Working on a material at my level is the } \\
\text { most productive } \\
\text { - I am most confident with what, where, } \\
\text { when questions }\end{array}$ & $\begin{array}{l}\text { - When the topic is relevant to my major of study, I } \\
\text { am MORE willing to read difficult English } \\
\text { materials. } \\
\text { - Long and complicated texts are still not for my } \\
\text { level at this stage } \\
\text { - Working on a material a little bit higher than my } \\
\text { level is the most productive } \\
\text { - Although I am most confident with what, where, } \\
\text { when questions, working with inference questions } \\
\text { helped me improved }\end{array}$ \\
\hline Social sharing & $\begin{array}{l}\text { - I am not confident to interact and discuss } \\
\text { the answers with my classmate in reading } \\
\text { tasks. } \\
\text { - Reading has often been an individual and } \\
\text { silent activity to me }\end{array}$ & $\begin{array}{l}\text { - I was more confident to interact and discuss the } \\
\text { answers with my classmate in reading tasks. } \\
\text { - We are more willing to read and share short and } \\
\text { interesting texts. For example, short-posts written in } \\
\text { English that shared on the facebook, English } \\
\text { learning tips and strategies, news headings, } \\
\text { proverbs... } \\
\text { - I sometimes send short messages written by } \\
\text { myself in English } \\
\text { - I did my home assignment more carefully so that I } \\
\text { can take part in the next whole class discussion }\end{array}$ \\
\hline
\end{tabular}

\section{CONCLUSION AND RECOMMENDATION}

The study results informed and described the impact of the experiment on the students' motivational constructs and practices. Importantly, this experiment measured how the sub-constructs of EFL reading motivation were influenced at both of their belief and action levels. It can be concluded that when classroom tasks support students to read to fill up their own purposes, an increase in reading motivation and a more positive attitude toward reading have been confirmed. This study also showed that the experiment was able to make the students more confident, autonomy in their learning. As a noticeable contribution to the literature, both of the questionnaire and interview data confirmed that among the investigated constructs, changes were more observable and explainable in the four constructs of curiosity, involvement, challenge, and social sharing. The student participants were more curious and involved themselves more in challenged reading tasks and social activities related to English written texts. A more autonomy learning habit inside and outside classroom was also reported to be formulated during the time of the experiment. Meanwhile, four constructs of competition, recognition, compliance, grade passing seemed to be more stable against the teaching method. Noticeably, they still showed a strong motivation to learn for higher score and a resistant to competition behaviors. Low proficiency learners considered that they lacked the special abilities to learn English well, tended to believe translation was an important skill to help them grasp the meanings of English texts, were least likely to control their affective states to cope with demotivating experiences [24], [34]

Based on the result, the author would recommend that teachers should not be too dependent on the lookauthentic text and the pre-designed reading tasks in any chosen course book, he/she should redesign the task where necessary to allow more individual reading purposes to be achieved. Importantly, they would recognize that the classroom events would be still controllable if a master plan for the task is provided. Breen [10] and Rusmawaty et al. [63] argued that that bringing authentic and real world into the classroom cannot be the essence of what is meant by authenticity unless all learners can understand of the target language conventions which leads to the interpretation of the meaning embedded in the both the text, tasks, and the classroom and the actual social situation in which learning takes place. It is claimed that language learning will result from creating the right kinds of interactional processes in the classroom, and the best way is using specially designed instructional and functional tasks. Although the hardest thing to do was to control and organize the activities, making reading more meaningful to learners by individualizing reading activities as the experiment in this study not only motivated students to read but also made classroom 
reading activities more interesting and engagement. In fact, the classroom evens in the experiment were less predictable and the students had many pedagogical as well as practical needs and goals. However, as an ELS teacher, we might posit that "authenticity" lies not only in the "genuineness" of text, but has much to do with the notion of task [21], [22]. Besides, what happens in learning should not be seen as something unilaterally in the hands of the teacher [3], learners can also make decisions about how to achieve their learning goals [77]. Lastly, futher research would need to organize larger number of participants as well as manage the differences in learning ability more strictly to improve the significance of the data and the result.

\section{REFERENCES}

[1] R. Y. Abdulhussein, "Investigating EFL college teachers' and learners' attitude toward using authentic reading materials in Misan", Procedia-Social and Behavioral Sciences, vol. 136, pp. 330-343, 2014.

[2] S. Ahmed, "Authentic ELT materials in the language classroom: an overview", Journal of Applied Linguistics and Research, vol. 4(2), pp. 181-202, 2017.

[3] D. Allwright, D., "Contextual factors in classroom language learning: an overview", in Context in language learning and language understanding. K. MalmKja \& J. Williams (Eds.), Cambridge University Press, 1998, pp.115-134.

[4] O. Anmarkrud \& I. Braten, "Motivation for reading comprehension", Learning and Individual Differences, vol. 19, pp. 252-256, 2009.

[5] M. T. Apple, "Extensive reading and the motivation to read: A pilot study", Doshisha Studies in Language and Culture, vol. 8, pp. 193-212, 2005.

[6] R.S. Barbour \& J. Kitzinger, Developing focus group research: Politics, theory and practice. London: Sage, 1999.

[7] A. M. F Barcelos, Teachers' and students' beliefs within a Deweyan framework: conflict and influence. Unpublished doctoral dissertation. The university of Alabama, 2000.

[8] S. A. Berardo, "The use of authentic materials in the teaching of reading", The Reading Matrix, vol. 6(2), pp. 60-69, 2006.

[9] J. Beresova, "Authentic materials-enhancing language acquisition and cultural awareness", Procedia-Social and Behavioural, vol. 192, pp. 192-204, 2015.

[10] M. P. Breen, "Navigating the discourse: on what is learned in the language classroom", in Learners and Language Learning. Renanda, W.A., Jacobs, G.M. (Eds.), SEAMEO Regional Language Centre, Singapore, 1998, pp. 115-143.

[11] K. B. Cartwright, T. R. Marshall, \& E. Wray, "A longitudinal study of the role of reading motivation in primary students' reading comprehension: Implications for a less simple view of reading”, Reading Psychology, vol. 37, pp. 55-91, 2016.

[12] A. Chalak, "The effect of task-based instruction on reading comprehension of Iranian EFL learners", Applied Research on English Language, vol. 4(1), pp. 19-29, 2015.

[13] I. N. Chiang, "Extra-curricular reading in Taiwan", The Asian EFL Journal, vol. 80, pp. 4-33, 2014.

[14] P. C. Cubillo \& C. N. Brenes, "Using Task-based Instruction in an ESP Course in the Computer Center at the University of Costa Rica”, Actualidades Investigativas en Educación, vol. 9(1), pp. 1-25, 2009.

[15] R. R. Day \& J. Bamford. Extensive reading in the second language classroom. Cambridge: Cambridge University Press, 1998. 
[16] R. De Burgh-Hirabe \& A. Feryok, “A model of motivation for extensive reading in Japanese as a foreign language", Reading in a Foreign Language, vol. 25(1), pp. 72-93, 2013.

[17] J. De Naeghel, H. Van Keer, M. Vansteenkiste, \& Y. Rosseel, “The relation between elementary learners' recreational and academic reading motivation, reading frequency, engagement, and comprehension: A selfdetermination theory perspective", Journal of Educational Psychology, vol. 104(4), pp. 1006-1021, 2012.

[18] K. V. Dhanapala, "Intrinsic motivation, extrinsic motivation and L2 reading comprehension of university learners in Japan and Sri Lanka”, Proceedings of the JACET Summer Seminar, Japan, vol. 6, pp. 39-43, 2006.

[19] N. K. Duke \& P. D. Pearson, "Effective practices for developing reading comprehension", in What research has to say about reading instruction, A.E. Farstrup \& S.J. Samuels (Eds.), Newark, DE: International Reading Association, 2002, pp. 205-242.

[20] R. Ellis, "Task-based research and language pedagogy”, Language teaching research, vol. 4 (3), pp. 193-220, 2000.

[21] R. Ellis. Task-based language learning and teaching. Oxford: Oxford University Press, 2003.

[22] R. Ellis, "Task-based language teaching: sorting out them is understandings", International Journal of Applied Linguistics, vol. 19(3), pp. 221-246, 2009.

[23] C. Y. Ersanli, "Improving technological pedagogical knowledge (TPACK) of pre-service English language teachers", International Education Studies, vol. 9(5), pp. 18-27, 2016.

[24] J. Falout, J, Elwood, \& M. Hood, "Demotivation: affective states and learning outcomes”, System, vol. 37(3), pp. 403-417, 2009.

[25] L. B. Gambrell, B. M. Palmer, R. M. Codling, \& S. A. Mazzoni, “Assessing motivation to read”, The Reading Teacher, vol. 49 (7), pp. 518-533, 1996.

[26] L. B. Gambrell, "Motivation in the school reading curriculum", in Rebuilding the foundation: Effective reading instruction for 21 st century literacy, T.V. Rasinski, Bloomington, IN: Solution Tree, pp. 41-65, 2011.

[27] S. R. Goldman \& J. A. Rakestraw, J.A, "Structural aspects of constructing meaning from text", in Handbook of reading research, M.L. Kamil, P.D. Pearson, \& R. Barr, Mahwah, NJ: Erlbaum, pp. 311-335, 2000.

[28] B. G. Glaser \& A. L. Strauss, The discovery of grounded theory: strategies for qualitative research. Aldine Transaction, Transaction Publishers, 2009.

[29] W. Guariento \& J. Morley, “Text and task authenticity in the EFL classroom”, ELT Journal, vol. 55(4), pp. 347-353, 2001.

[30] J. Guthrie \& A. Wigfield, Motivating reading comprehension: concept oriented reading instruction. Taylor \& Francis E-Library, 2000.

[31] A. O. Hadley. Teaching language in context (3rd ed.). Boston: Heinle\& Heinle Publishers, 2003.

[32] C. Hosenfeld, "Evidence of emergent beliefs of a second language learner: a diary study", in Beliefs about SLA. Kalaja, P. \& Barcelos, A. M. F. Kluwer Academic Publishers, 2003, pp. 37-54.

[33] H, Huang, "Motivational changes in an English foreign language online reading context", Social Behavior \& Personality: An International Journal, vol. 41(5), pp. 715-720, 2013.

[34] S. C. Huang \& R. R. Tsai, A comparison between high and low English proficiency learners' beliefs. ERIC Document, 2003. Retrieved from https://eric.ed.gov/?id=ED482579 
[35] P. B. Judge, "Driven to read: Enthusiastic readers in a Japanese high school's extensive reading program", Reading in a Foreign Language, vol. 23, pp. 161-186, 2011.

[36] P. Kalaja, "Research on students' beliefs about SLA within a discursive approach", In Beliefs about SLA. Kalaja P. \& A. M. F. Barcelos, Kluwer Academic Publishers, 2003, pp. 87-108.

[37] B. Kamalian, "The Effect of Task-based Reading Activities on Vocabulary Learning and Retention of Iranian EFL Learners", The Journal of Asia TEFL, vol. 14(1), pp. 32-46, 2017.

[38] M. Keihaniyan, "The effect of post-reading questions on vocabulary learning", International Journal of Management and Humanity Sciences, vol. 3(1), pp. 1197-1202, 2014.

[39] Y. Kim \& N. Tracy-Ventura, "The role of task repetition in L2 performance development: What needs to be repeated during task-based interaction?", System, vol. 41, pp. 829-840, 2013.

[40] R. Komiyama, "Factors underlying second language reading motivation of adult EAP students". Reading in a Foreign Language, vol. 25(2), pp. 149-169, 2013.

[41] C. Kramsch. Context and culture in language teaching. Oxford University Press, 1993.

[42] R. A. Krueger \& M. A. Casey. Focus groups. Thousand Oaks CA: Sage, 2000.

[43] M. H. Long, Second language acquisition and task-based language teaching. UK: John Wiley \& Sons Ltd, 2015.

[44] K. Lau, "Construction and initial validation of the Chinese Reading Motivation Questionnaire", Educational Psychology, vol. 24, pp. 845-865, 2004.

[45] D. Lin, K. K. Wong, \& C. McBride-Chang, "Reading motivation and reading comprehension in Chinese and English among bilingual students”, Reading and Writing, vol. 25, pp. 717-737, 2012.

[46] R. Lyster, "Using form-focused tasks to integrate language across the immersion curriculum", System, vol. 43, pp. 1-10, 2014.

[47] J. Mante-Estacio, "Dimensions of reading motivation on Filipino bilinguals", TESOL Journal, vol. 7, pp. 1029, 2012.

[48] H. D. Marcia, M. T. Stephen, H. Michael, W. Wenhao, \& R. Aldo, "A review of reading motivation scales", Reading Psychology, vol. 39(2), pp. 121-187, 2018.

[49] M. C. McKenna, K. Conradi, C. Lawrence, B. J. Jang, \& J. P. Meyer, "Reading attitude of middle school students: results of a U.S. survey ”, Reading Research Quarterly, vol. 47(3), pp. 283-30, 2012.

[50] M. McLaughlin, "Reading Comprehension: What Every Teacher Needs to Know", The Reading Teacher, vol. 65(7), pp. 432- 440, 2012.

[51] D. Narvaez, "Individual differences that affect reading comprehension", In Comprehension instruction, M. Pressley \& C. Bloc (Eds.), Guilford, 2001, pp.158-175.

[52] N. Nahavandi \& J. Mukundan. "Task-based cycle in reading comprehension classes", International Journal of Applied Linguistics \& English Literature, vol. 2(2), pp. 107-113, 2013.

[53] D. Nunan, Aspects of Task-Based Syllabus Design, Hong Kong, 2001. Retrieved from http:// www.telus.net/linguistic issues/syllabus design.html-20-k

[54] D. Nunan. Task-based language teaching. Cambridge: CUP, 2004.

[55] Y. Ozek \& M. Civelek, "A study on the use of cognitive reading strategies by ELT students", The Asian EFL Journal, Professional Teachers Articles, pp. 1-16, 2006. 
[56] A. S. Palincsar \&A. L. Brown, "Reciprocal teaching of comprehension fostering and monitoring activities", Cognition and Instruction, vol. 1(2), pp. 117-175, 1984.

[57] M. Poorahmadi, "Investigating the efficiency of task-based instruction in improving reading comprehension ability”, Journal of language and translation, vol. 3(1), pp. 29-36, 2012.

[58] M. Pressley, "What should comprehension instruction be the instruction of?", in Handbook of reading research, M.L. Kamil, P.B. Mosenthal, P.D. Pearson, \& R. Barr, Mahwah, NJ: Erlbaum, 2000, pp. 545-561.

[59] E. Ro, “A case study of extensive reading with an unmotivated L2 reader”, Reading in a Foreign Language, vol. 25, pp. 213-233, 2013.

[60] E. Ro, “Exploring teachers' practices and students' perceptions of extensive reading approach in EAP reading classes”, Journal of English for Academic Purposes, vol. 22, pp. 32-41, 2013.

[61] E. Ro, "Understanding reading motivation from EAP students' categorical work in a focus group", TESOL Quarterly, vol. 52(4), pp. 772-797, 2017.

[62] L. R. Roehler \& G. G. Duffy, "Direct explanation of comprehension processes", In Comprehension instruction: Perspectives and suggestions, G.G. Duffy, L.R. Roehler, \& J. Mason, Longman, 1984, pp. 265-280.

[63] D. Rusmawaty, H. Atmowardoyo, A. Hamra, N. Noni, "Teachers' beliefs of authentic materials for teaching reading in Indonesian EFL classrooms”, Journal of Language Teaching and Research, vol. 9(3), pp. 608-613, 2018.

[64] M. Saeidi \& H. Ahmadi, “The Effects of Watching Videos in Pre-reading on EFL Learners' Reading Comprehension and Attitudes", TESOL International Journal, vol.11(2), pp. 15-44, 2016.

[65] L. T. A. B. Sembiring, D. Rukmini, J. Mujiyanto, \& Y. Yuliasri, "The impact of comprehension instruction on students' reading comprehension with different ability grouping and self-efficacy", TESOL International Journal, vol. 13(4), pp. 156-171, 2018.

[66] U. Schiefele, E. Schaffner, J. Moller, \& A. Wigfield, "Dimensions of reading motivation and their relation to reading behavior and competence", Reading Research Quarterly, vol. 47, pp. 427-463, 2012.

[67] T. Stoeckel, N. Reagan, \& F. Hann, "Extensive reading quizzes and reading attitudes", TESOL Quarterly, vol. 46, pp. 187-198, 2012.

[68] L. Tercanlioglu, "The nature of turkish students' motivation for reading and its relation to their reading frequency", The Reading Matrix, vol. 1(2), pp. 1-33, 2001.

[69] B, Tomlinson, "Materials development for language learning and teaching", Language Teaching, vol. 45(2), pp. 143-179, 2012.

[70] J. H. Wang, \& J. T. Guthrie, "Modeling the effects of intrinsic motivation, extrinsic motivation, amount of reading, and past reading achievement on text comprehension between U.S. and Chinese students", Reading Research Quarterly, vol. 39, pp. 162-186, 2004.

[71] F. Waninge, Z. Dörnyei, \& K. De Bot, "Motivational dynamics in language learning: change, stability, and context”, The Modern Language Journal, vol. 98(3), pp. 704-723, 2014.

[72] C. Wallace, "Reading", In The Cambridge guide to teaching English to speakers of other languages, R. Carter, \& D. Nunan (Eds.), Cambridge: Cambridge University Press, 2001.

[73] H. G. Widdowson. Learning purpose and language use. London: Oxford University Press, 1983. 
[74] A. Wigfield \& J. T. Guthrie, "Relations of children's motivation for reading to the amount and breadth of their reading", Journal of Educational Psychology, vol. 89(3), pp. 420-432, 1997.

[75] A. Wigfield, "Reading motivation: a domain-specific approach to motivation", Educational Psychologist, vol. 32, pp. 59-68, 1997.

[76] D. Willis. A Framework for Task-based Learning, London, Longman, 1996.

[77] D, Woods, "Decision-making in language learning: a lens for examining learner strategies", 1997. Retrieved from: http://jalt-publications.org/old_tlt/files/97/oct/woods.html.

[78] Z. Zohoorian \& A. Pandian, "An evaluation of authenticity: a case of EAP textbooks in Iran", International Journal of Languages and Literatures, vol. 2(1), pp. 91-113, 2014.

\section{Appendix}

This form is adapted from the The Motivation for Reading in English Questionnaire (MREQ) by Komiyama (2013) is for students of English as a second or foreign language. On the separate works sheet, write the response (1, 2,3 or 4 ) that tells how true of you the statement is.

1. Very different from me (means that the statement is not true of you almost always)

2. A little different from me (means is not true less than half the time)

3. A little like me (the statement is true less than half the time of you almost always)

4. A lot like me (the statement is true of you about half the time)

Answer in terms of how well the statement describes you. There are no right or wrong answers to these statements. Thank you.

Students' Number: (please write the number given by your teacher)

Instruction: Please circle one alternative for each statement according to the amount of your agreement or disagreement $(1,2,3$ or 4$)$ with that item.

\begin{tabular}{|c|c|c|c|c|c|c|}
\hline $\begin{array}{l}\text { Ite } \\
\text { ms }\end{array}$ & Statement & $\begin{array}{l}\text { Classification } \\
\text { (hidden in the } \\
\text { printed version used }\end{array}$ & \multicolumn{4}{|c|}{ Scale } \\
\hline 1 & $\begin{array}{l}\text { I like reading in English to learn something new about } \\
\text { people and things that interest me. }\end{array}$ & Curiosity & 1 & 2 & 3 & 4 \\
\hline 2 & I like reading a lot of interesting things in English. & Involvement & 1 & 2 & 3 & 4 \\
\hline 3 & $\begin{array}{l}\text { I feel happy when I read about something interesting in } \\
\text { English. }\end{array}$ & Curiosity & 1 & 2 & 3 & 4 \\
\hline 4 & $\begin{array}{l}\text { When the topic is interesting, I am willing to read difficult } \\
\text { English materials. }\end{array}$ & Challenge & 1 & 2 & 3 & 4 \\
\hline 5 & It's fun for me to read about something I like in English. & Involvement & 1 & 2 & 3 & 4 \\
\hline 6 & $\begin{array}{l}\text { It is hard for me to stop reading in English when the topic } \\
\text { is interesting. }\end{array}$ & Involvement & 1 & 2 & 3 & 4 \\
\hline 7 & I like reading about new things in English & Curiosity & 1 & 2 & 5 & 4 \\
\hline 8 & $\begin{array}{l}\text { I enjoy reading when I learn complex ideas from English } \\
\text { materials. }\end{array}$ & Challenge & 1 & 2 & 3 & 4 \\
\hline 9 & $\begin{array}{l}\text { I like it when the topic of an English reading makes me } \\
\text { think a little more. }\end{array}$ & Challenge & 1 & 2 & 3 & 4 \\
\hline 10 & I like challenging myself while reading in English. & Challenge & 1 & 2 & 3 & 4 \\
\hline 11 & I enjoy reading good, long stories in English. & Involvement & 1 & 2 & 3 & 4 \\
\hline 12 & I like hard, challenging English readings. & Challenge & 1 & 2 & 3 & 4 \\
\hline 13 & $\begin{array}{l}\text { When an assignment is interesting, I can read difficult } \\
\text { English materials more easily. }\end{array}$ & Challenge & 1 & 2 & 3 & 4 \\
\hline 14 & $\begin{array}{l}\text { When I am reading about an interesting topic in English, I } \\
\text { sometimes lose track of time. }\end{array}$ & Involvement & 1 & 2 & 5 & 4 \\
\hline
\end{tabular}




\begin{tabular}{|c|c|c|c|c|c|c|}
\hline 15 & $\begin{array}{l}\text { When my teacher or friends tell me something interesting, } \\
\text { I might read more about it in English. }\end{array}$ & Curiosity & 1 & 2 & 3 & 4 \\
\hline 16 & $\begin{array}{l}\text { I enjoy reading in English to learn what is going on in } \\
\text { English-Speaking countries }\end{array}$ & Curiosity & 1 & 2 & 3 & 4 \\
\hline 17 & $\begin{array}{l}\text { I am willing to work hard to read better than my } \\
\text { friends/classmates in English. }\end{array}$ & Competition & 1 & 2 & 3 & 4 \\
\hline 18 & $\begin{array}{l}\text { I like being the only student who knows an answer about } \\
\text { something we read in English. }\end{array}$ & Competition & 1 & 2 & 3 & 4 \\
\hline 19 & I like my teacher to say that I read well in English. & Recognition & 1 & 2 & 3 & 4 \\
\hline 20 & $\begin{array}{l}\text { When I complete English reading assignments for class, I } \\
\text { try to get more answers correct than my classmates. }\end{array}$ & Competition & 1 & 2 & 3 & 4 \\
\hline 21 & $\begin{array}{l}\text { When I read in English, I like to finish my reading } \\
\text { assignments before other students. }\end{array}$ & Competition & 1 & 2 & 3 & 4 \\
\hline 22 & I like my friends to tell me that I am a good English reader. & Recognition & 1 & 2 & 3 & 4 \\
\hline 23 & I want to be the best at reading in English. & Competition & 1 & 2 & 3 & 4 \\
\hline 24 & $\begin{array}{l}\text { When some classmates read English better than me, I want } \\
\text { to read more English materials. }\end{array}$ & Competition & 1 & 2 & 3 & 4 \\
\hline 25 & $\begin{array}{l}\text { I would like it when my teacher asks me to read English } \\
\text { aloud in class/explain my answer aloud in class. }\end{array}$ & Recognition & 1 & 2 & 3 & 4 \\
\hline 26 & $\begin{array}{l}\text { I would like to get positive comments about my English } \\
\text { reading. }\end{array}$ & Recognition & 1 & 2 & 3 & 4 \\
\hline 27 & $\begin{array}{l}\text { When I read in English, I often think about how well I read } \\
\text { compared to others. }\end{array}$ & Competition & 1 & 2 & 3 & 4 \\
\hline 28 & $\begin{array}{l}\text { I practice reading in English because I feel good when I } \\
\text { answer teachers' questions correctly in class. }\end{array}$ & Recognition & 1 & 2 & 3 & 4 \\
\hline 29 & $\begin{array}{l}\text { I would feel happy when/if my friends ask me for help } \\
\text { with their English reading assignments. }\end{array}$ & Recognition & 1 & 2 & 3 & 4 \\
\hline 30 & $\begin{array}{l}\text { Finishing English reading assignments on time is very } \\
\text { important for me. }\end{array}$ & Compliance & 1 & 2 & 3 & 4 \\
\hline 31 & $\begin{array}{l}\text { I usually try to finish my English reading assignments on } \\
\text { time. }\end{array}$ & Compliance & 1 & 2 & 3 & 4 \\
\hline 32 & $\begin{array}{l}\text { It is important for me to receive a good grade in my } \\
\text { English reading course. }\end{array}$ & Grade & 1 & 2 & 3 & 4 \\
\hline 33 & $\begin{array}{l}\text { I do my English reading assignments exactly as the teacher } \\
\text { tells me to do them. }\end{array}$ & Compliance & 1 & 2 & 3 & 4 \\
\hline 34 & I look forward to finding out my grades in English reading. & Grade & 1 & 2 & 3 & 4 \\
\hline 35 & I want to read in English to improve my grades. & Grade & 1 & 2 & 3 & 4 \\
\hline 36 & $\begin{array}{l}\text { I work harder on English reading assignments when they } \\
\text { are graded. }\end{array}$ & Grade & 1 & 2 & 3 & 4 \\
\hline 37 & $\begin{array}{l}\text { I try to read in English because I need a good score on } \\
\text { tests like TOEIC, TOEFL, Michigan, Cambridge CEFR, } \\
\text { IELTS, etc. }\end{array}$ & Gain Score & 1 & 2 & 3 & 4 \\
\hline 38 & $\begin{array}{l}\text { I try to read in English because I like seeing my reading } \\
\text { score improve on tests like TOEIC, TOEFL, Michigan, } \\
\text { Cambridge CEFR, IELTS, etc. }\end{array}$ & Gain Score & 1 & 2 & 3 & 4 \\
\hline 39 & $\begin{array}{l}\text { I practice reading in English because I want a higher } \\
\text { reading score than my friends and classmates on tests like } \\
\text { TOEIC, TOEFL, Michigan, Cambridge CEFR, IELTS, etc. }\end{array}$ & Competition & 1 & 2 & 3 & 4 \\
\hline 40 & $\begin{array}{l}\text { I practice reading in English because I need to do well in } \\
\text { my future classes. }\end{array}$ & Compliance & 1 & 2 & 3 & 4 \\
\hline 41 & $\begin{array}{l}\text { I enjoy telling my friends about the things I read in English } \\
\text { materials. }\end{array}$ & Social sharing & 1 & 2 & 3 & 4 \\
\hline 42 & My friends and I like to share what we read in English. & Social sharing & 1 & 2 & 3 & 4 \\
\hline 43 & I like talking with my friends about what I read in English. & Social sharing & 1 & 2 & 3 & 4 \\
\hline 44 & $\begin{array}{l}\text { I like joining class discussions about what I read in } \\
\text { English. }\end{array}$ & Social sharing & 1 & 2 & 3 & 4 \\
\hline
\end{tabular}




\begin{tabular}{|c|l|c|cccc|}
\hline 45 & $\begin{array}{l}\text { I am happy when someone know about my ability in } \\
\text { English Reading. }\end{array}$ & Recognition & 1 & 2 & 3 & 4 \\
\hline 46 & $\begin{array}{l}\text { I try to read in English so I can understand what my } \\
\text { friends are talking about. }\end{array}$ & Social sharing & 1 & 2 & 3 & 4 \\
\hline 47 & $\begin{array}{l}\text { I read in English with the aim to pass in English course. } \\
\text { Course }\end{array}$ & $\begin{array}{c}\text { Pasing English } \\
\text { Course }\end{array}$ & 1 & 2 & 3 & 4 \\
\hline
\end{tabular}

\section{TÁC ĐỘNG CỦA PHƯƠNG PHÁP CÁ NHÂN HOÁ MỤC ĐÍCH CÁC B ÀI TậP LÊN ĐộNG LỤ๋C HỌC TẬP MÔN ĐỌC HIỂU CỦA SINH VIÊN}

Tóm tắt. Mục đích của nghiên cứu là đi tìm tác động của việc giao bài tập đọc hiểu theo mục tiêu, sở thích của từng cá nhân người học lên động lực học tập và thực hành của sinh viên không chuyên. Phương pháp thực nghiệm được thực hiện và so sánh hai nhóm đối tượng, mỗi nhóm 35 sinh viên không chuyên trong môn học tiếng Anh. Công cụ lấy dữ liệu và bảng câu hỏi khảo sát MRQ và phỏng vấn theo nhóm. T-Test và One WAY ANOVA được thực hiện và kết quả cho thấy phương pháp có những tác động rõ rệt lê động lực học tập và hành vi học tập hằng ngày của người học. Đặc biệt, kết quả cho thấy có tác động với các mức độ khác nhau lên các cấu thành của động lực học tập môn đọc hiểu.

Từ khoá: động lục hoc tập môn đọc hiểu, luyện tập môn đọc hiểu. 